\title{
Theoretical and methodological reflection of a case study on the Deblínsko landscape project
}

\author{
Alois Hynek, Břetislav Svozil, Jakub Trojan, Jan Trávníček \\ Envigogika 10 (2) - Reviewed Papers/ Recenzované články
}

Publikováno/Published dne 25. 4. 2015

DOI: $\underline{10.14712 / 18023061.477}$

\begin{abstract}
:
The case study is based primarily on long-standing collaboration of two public sector institutions: the MU in Brno and the Deblín Primary School and Kindergarten, with cooperation of experts in numerous other institutions. The MU in Brno and the Deblín Primary School and Kindergarten focus on research, teaching and, above all, practical applications of sustainability/security. The objective of the study is to revise the theoretical and methodological frameworks influencing approaches to teaching sustainability in primary education and, through it, to open a discussion of civic society topics and formation starting at the level of children/pupils/students. The vehicle for achieving the objective is a thorough critical view of the "Deblínsko landscape project". The authors' experience concerns development of dialogue between the world of science and its applications and needs of those on whom its consequences impact. They are collected as part of activities aimed primarily at intensive field and project teaching, which reflects the sustainability discourse in the primary, secondary and tertiary education practice and is also connected with establishment of international collaboration. The focus of the field work is based on the understanding of each of the institutions as regional education centres (Deblín Primary School and Kindergarten = community centre), focused on solving issues of sustainability, involving owners, users, decision-makers, shareholders and stakeholders within public territorial administration, represented by means of goals and measures of regional development schemes along with micro-regional development programmes and local action group (LAG) activities.
\end{abstract}

\section{Key words:}

primary school; regional university; local community; participatory action research; rural sustainability

\section{Abstrakt:}

Případová studie vychází primárně z mnohaleté spolupráce dvou institucí veřejného sektoru - MU Brno a ZŠ a MŠ Deblín, které se zaměřují na výzkum, výuku a především praktické aplikace trvalé udržitelnosti/bezpečnosti. Cílem studie bylo a je otevř́t diskurz nad tématy, vytvářet občanskou společnost od úrovně dětí/žáků/studentů při schopnosti 
umět odhalit nedostatky uplatněním transdisciplinárního přístupu ve studiu krajinných ekosystémů.

Naše zkušenosti směřují k rozvíjení dialogu mezi světem vědy a jejích aplikací s potřebami těch, na něž její důsledky dopadají. Děje se tak $v$ rámci aktivit směřovaných především $\mathrm{k}$ intenzivní terénní a projektové výuce, včleněním do diskurzu trvalé udržitelnosti $v$ praxi ZŠ, SŠ a VŠ s navázáním mezinárodní spolupráce. Zaměření terénní práce vychází z chápání jednotlivých pracovišt jako regionálních center vzdělanosti (ZŠ a MŠ Deblín = komunitní centrum), která se zaměřují především $\mathrm{k}$ řešení témat trvalé udržitelnosti zahrnujících vlastníky, uživatele, rozhodovatelé, podílníky a dotčené $v$ rámci veřejné správy území reprezentované prostřednictvím cílů a opatření krajských programů regionálního rozvoje s programy rozvoje mikroregionů a činností místních akčních skupin (MAS).

\section{Klíčová slova:}

základní škola; regionální univerzita; místní komunita; participativní akční výzkum; udržitelný rozvoj venkova 


\section{Introduction}

The present study is the outcome of collaborative work on development of study materials concerned with education for sustainability. The section on methods describes the theoretical frameworks of the project, chiefly the chosen approaches to participatory action research, the importance of revised taxonomies of educational goals, and translation of the dispositif concept into a matrix for sustainability educational themes. One of the preconditions of functionality of the approach is the recognition of pupils as engaged citizens of the community, as described in the conclusion of chapter 2. Following a brief summary of results (chapter 3 ) is a discussion of the specific impacts of the methodological development on teaching at the MU Department of Geography and the Deblín project as such. The study structure thus reflects the main objective of the paper, which is to revise the theoretical and methodological concepts informing innovations in approaches to sustainability education in primary schools in order to open a critical discussion of civic society issues. The core of the study is based on a transcription of significant outcomes of the Deblínsko landscape project, used as a best practice example in environmental education.

\section{Historic context of developing approaches to sustainability teaching}

Thanks to its interdisciplinary focus, interest in landscape issues in all their spatial contexts, and emphasis on a dynamic view of natural and social phenomena, the discipline of geography is highly suited for handling practical issues of sustainable development. In the Czech setting, its relationship with environmental issues has been forming for many years, with certain difficulties and shifts in understanding of both the environment and the role of geographic research within it.

The first seminar on a geographic approach to the environment was held at the Department of Geography of the Faculty of Science of then J.E. Purkyně University (UJEP, present-day Department of Geography of the Faculty of Science of Masaryk University) in September 1973. The reason was an effort to keep up with the international development in delicate questions of its deteriorating quality. The 'environment' topic was very difficult to promote in then Czechoslovakia, under the conditions of an extensive 'command economy', but there were individual environmentalists as well as groups who managed to defend their position versus the political regime. Along with the satellites of the Soviet Union, the Czechoslovak government refused to participate at the global conference on human environment in Stockholm in 1972 as a consequence of the German Democratic Republic not having been invited. Even back then, the geographic institute of the UJEP knew about an important document of the US government: The 1969 National Environmental Policy Act - an act of law on establishing a national environmental policy aiming at setting up an Environmental Quality Board. Opening the 'environment' topic internationally was a fundamental challenge in studying the issues in geography, particularly by implementing landscape studies as a study of a set of landscape ecosystems.

Another impetus for environmental studies at then Department of Geography of the Faculty of Science of then J.E. Purkyně University in Brno (UJEP, original and present-day Masaryk University) was the activity of the IUCN (International Union for Conservation of Nature), in which Professor V. Vaníček of Mendel University in Brno was actively involved; he was recognised for his activities at the European level later on, after November 1989. He collaborated with the UJEP Geography Department on developing a strategy for the development of the Fryšávka basin (Hynek et al., 1985). The strategy was based on the 
important World Conservation Strategy (1980), published by the IUCN. It contained the first mention of the 'sustainable development' concept, followed in 1987 by Our Common Future, also known as the Brundtland Report, and more precisely as the Report of the World Commission on Environment and Development: Our Common Future.

It would be naïve to think that November 1989 meant a total reversal in the Czech society's attitude to environmental issues. Some conservatively and liberally oriented politicians have questioned (chiefly in the media) the 'sustainability' concept and preferred revenues at the expense of environmental degradation. In contrast to that, Kates, Parris and Leiserowitz (2005) consider the 'environment' topic as important as peace, freedom and development. It is the regard for future generations that has the ability to make development sustainable, which contrasts with attitudes that see nature as a source without limits to its exploitation.

Nevertheless, the application of the sustainability concept in our education and research is fundamentally influenced by the set of documents Millennium Ecosystem Assessment from 2003 (Alcamo J. et al. 2003), the development of which involved the Czech Professor B. Moldan, Director of the Charles University Environment Centre in Prague.

Innovation of the IUCN's efforts for sustainability consists in the conclusions of a consultation formulated by Adams (2006), chiefly the solution to the duality of the necessary long-term structural changes and short-term interests of the poor, supported with locked markets, financial institutions, shareholders and politicians. This also concerns the relationship between sustainability and the Millennium Development Goals, which ought to be in consonance (see Grigga et al., 2013). We can refer to the significant shift in seeking paths towards sustainability as to the Rio (de Janeiro) Process - commenced with the 1992 Rio Declaration on Environment and Development - Conference on Environment and Development (UNCED). So far the latest sequel to this process was the Earth Summit Rio+20 in 2012, the outcomes of which the UNEP interpreted in Our Planet with the paper From Outcome to Implementation. An overview of the succession of international conferences dealing with education for environmental sustainability is provided by, e.g. Wright (2002).

However, application of new approaches and concepts of sustainability as they have been forming progressively in the international and Czech (professional) community, and have impacted on sustainability practice as well, has always depended on the ability to elaborate them for specific conditions and context. Such efforts are mostly initiated by bottom-up activity and take place with the involvement of various stakeholders, such as the long-term effort of teachers and students of Masaryk University in Brno for collaboration with citizens (pupils, teachers, local authorities) at the local level described below. The collaboration project has already been described in related papers (Hynek et al., 2009, 2010, 2011); here, we primarily specify the main starting points and potential for implementation of other similar collaboration projects between a university and a local community, mediated by the primary school in the given area.

\section{Methods}

The model Deblínsko project includes an academic component (represented by research, which plays a cognitive as well as a metacognitive role), an educational component (at several levels: education for Masaryk University students, pupils at the local school, as well as "social learning" taking place among all those involved; see the 
conclusion), and finally, a practical component (involving the launch of processes relating to development of the municipality or its cultural, natural, etc. resources). Each of these components is based on different points of departure, which we will briefly outline in this overview.

In the research section, we work with the true meaning of participatory action research, which is used for studying people's material conditions - incomes, housing, environment, jobs, healthcare. The point is not only acquisition of information but above all its application; not proving of hypotheses but building and empowering of communities, mutual understanding, deepening of relationships and enforcement of changes. Within it, we carry out communities surveys, one-to-one interviews, group discussions, we participate in social/cultural events, listen to stories, historic memories, and investigate people's biographies just as we do statistics. This concept is followed by action research.

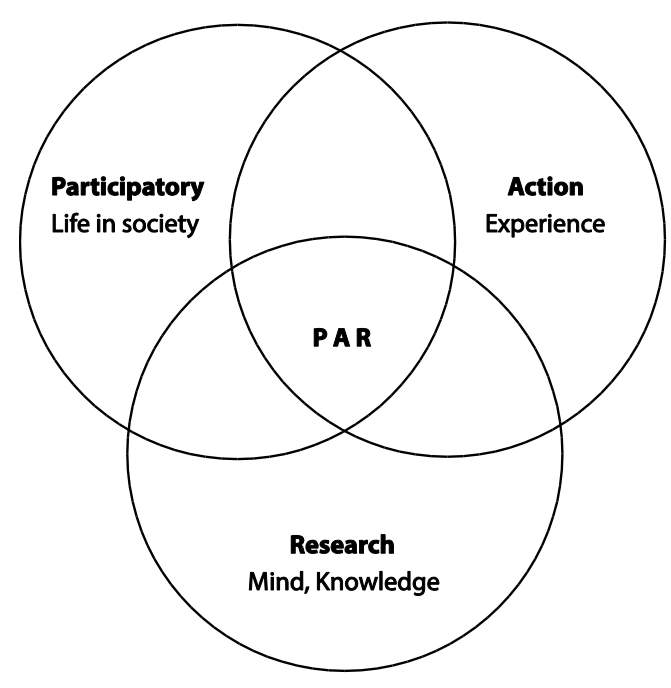

Fig. 1: Participatory action research, Chevalier and Buckles, 2013, p. 10

Berg (2004:196) understands action research as a practical strategy for managing social research requiring systematic, organised and premeditated investigation. Its practical impacts are no less important: adoption of the principles of participation, deliberation, empowerment and emancipation of people interested in improving their situation, the social conditions of their lives. Action research includes:

- A highly rigorous, yet premeditated or interpretative approach to empiric research.

- Integration of some practical outcomes relating to real lives of participants in the research project.

- A spiral of steps, each consisting of a certain type of planning, action and evaluation.

- Democratisation of knowledge production and application.

- $\quad$ Ethical fairness in benefits arising from the knowledge of the generation process.

- An ecological attitude to society and nature.

- Evaluation of human abilities of learning, change and deliberation.

- A commitment to non-violent social change. 
According to Berg (2004), participants/stakeholders in such research include, for instance, representative samples of the public (respondent groups), representatives of institutions (participants of fora within groups) and informal meetings or other meetings at various levels (municipal meetings). R. Kohoutek (2015) provides an apt definition of action research in social sciences: it is focused on cognition, evaluation and improvement of practice, e.g., educational, which is our case.

In the educational section, the guidance of university students at the Department of Geography of the MU Faculty of Science in the subjects of Sustainability and Urban and Rural Studies is based on adopting the 'educational objectives', which was first classified in a recognised way by Bloom et al. (1956). According to Vávra (in Hynek, Vávra, 2012, pp. 111-112), a revision of the taxonomy was made by Anderson and Krathwohl (2001). Consequently, it has two main dimensions/domains: the domain of knowledge and that of cognitive processes. As for knowledge, the authors include in it factual knowledge, conceptual knowledge, procedural knowledge, and what has been underestimated so far in the Czech educational system, metacognitive knowledge ). Anderson and Krathwohl (2001), and after all, even Marzano and Kendall (2006) thus abridge Bloom's taxonomy by adding the metacognitive levels including critical thinking and even identification with motivation - the process of awareness, application of information, own thinking, and implementation. Nilsson (2012) also adds the taxonomy used in the PISA - Programme for International Student Assessment, which newly puts an emphasis on information and communication technologies as well. Our geographic education practice also follows, among other things, the US national geographic standards (Heffron and Downs, 2012). The effort of Vávra (2011), involving his own interpretation of educational taxonomic objectives, has been promoted in the Czech geographic education system. Hynek and Vávra (2012) provide a deeper perspective of the geographic education.

Table 1: Taxonomies of educational objectives (Nilsson, 2012)

\begin{tabular}{|l|l|l|l|}
\hline Bloom (1956) & $\begin{array}{l}\text { Anderson \& } \\
\text { Krathwohl (2001) }\end{array}$ & $\begin{array}{l}\text { Marzano \& Kendall } \\
(2006)\end{array}$ & PISA (2000) \\
\hline Evaluation & Create & Self-System Thinking & Communicate \\
\hline Synthesis & Evaluate & Metacognition & Construct \\
\hline Analysis & Analyze & Knowledge Utilization & Evaluate \\
\hline Application & Apply & Analysis & Integrate \\
\hline Comprehension & Understand & Comprehension & Manage \\
\hline Knowledge & Remember & Retrieval & Access \\
\hline
\end{tabular}

The key context for the Deblínsko project is the setting of the field teaching/research practice. The current overview of the applied 'sustainability' concept in the field practice is shown in the table below, inspired by the "dispositif concept" according to Foucault (1999, 2000, pp. 374-5) as commented on by Deleuze (2003). It consists in combination of discursive and non-discursive practices that relate to the topic. The "dispositive" corresponds to institutional, physical and administrative mechanisms along with knowledge structures that reinforce and maintain governance. The following matrix (Table 2) for sustainability teaching, which would call for a separate paper by itself, represents the 
maximum extent of sustainability teaching guidance, from which required operations are always selected; nevertheless, the overall framework gives a true picture of the targetedness of the educational content in reference to the educational objectives specified above.

Table 2: Matrix for decoding rural sustainability in Foucault's "dispositive" mode (Hynek, 2013)

\begin{tabular}{|c|c|c|c|c|c|}
\hline Step & Identification & A & B & C & D \\
\hline 1 & $\begin{array}{l}\text { Natural landscape } \\
\text { ecosystems }\end{array}$ & Ecosystem services & $\begin{array}{l}\text { Supply } \\
\text { Stock/resources }\end{array}$ & $\begin{array}{l}\text { Geography } \\
\text { Geo-informatics/ } \\
\text { GIS }\end{array}$ & $\begin{array}{l}\text { Knowledge of local } \\
\text { environment } \\
\text { Cognition }\end{array}$ \\
\hline 2 & $\begin{array}{l}\text { Land use } \\
\text { Landscape cover }\end{array}$ & $\begin{array}{l}\text { Use } \\
\text { procedures/regimes } \\
\text { Technology } \\
\text { changes }\end{array}$ & $\begin{array}{l}\text { Stock/exploited } \\
\text { stock } \\
\text { Harvest } \\
\text { Yield }\end{array}$ & $\begin{array}{l}\text { Local use } \\
\text { Local food } \\
\text { Consumption }\end{array}$ & $\begin{array}{l}\text { Imports } \\
\text { Exports }\end{array}$ \\
\hline 3 & $\begin{array}{l}\text { Cultural landscape } \\
\text { ecosystems }\end{array}$ & $\begin{array}{l}\text { Productive } \\
\text { Protected }\end{array}$ & Bearing capacity & $\begin{array}{l}\text { Added nutrients } \\
\text { and energies }\end{array}$ & $\begin{array}{l}\text { Endangerment/ } \\
\text { degradation } \\
\text { Disasters/threats }\end{array}$ \\
\hline 4 & $\begin{array}{l}\text { Landscape gaze, } \\
\text { Environment } \\
\text { Perception of place } \\
\text { Power and } \\
\text { resistance }\end{array}$ & $\begin{array}{l}\text { Perception } \\
\text { Imagination/ } \\
\text { imagery } \\
\text { Representation } \\
\text { Spatial policy }\end{array}$ & $\begin{array}{l}\text { Mental maps } \\
\text { Biographies } \\
\text { Stories }\end{array}$ & $\begin{array}{l}\text { Landscape } \\
\text { Design } \\
\text { Heritage }\end{array}$ & $\begin{array}{l}\text { Inertia/ } \\
\text { changes } \\
\text { Environmental } \\
\text { footprint }\end{array}$ \\
\hline 5 & $\begin{array}{l}\text { Landscape policy } \\
\text { Participants and } \\
\text { implementers } \\
\text { Wellbeing } \\
\text { requirements } \\
\text { Transparency }\end{array}$ & $\begin{array}{l}\text { Owners } \\
\text { Tenants } \\
\text { Shareholders } \\
\text { Stakeholders } \\
\text { Decision-makers }\end{array}$ & $\begin{array}{l}\text { Planners } \\
\text { Experts } \\
\text { Companies }\end{array}$ & Implementers & $\begin{array}{l}\text { Political ecology } \\
\text { Locall } \\
\text { regional planning } \\
\text { Ecological diversity } \\
\text { Recreation } \\
\text { Spatiality }\end{array}$ \\
\hline 6 & $\begin{array}{l}\text { Local production } \\
\text { Savings } \\
\text { Incomes/livelihood }\end{array}$ & $\begin{array}{l}\text { Production factors, } \\
\text { Entrepreneurs } \\
\text { Market } \\
\text { Internal income } \\
\text { External income }\end{array}$ & $\begin{array}{l}\text { Internal and } \\
\text { external inputs } \\
\text { Labour market }\end{array}$ & $\begin{array}{l}\text { Outputs - } \\
\text { goods and services } \\
\text { Social income }\end{array}$ & $\begin{array}{l}\text { Production } \\
\text { Distribution } \\
\text { Exchange } \\
\text { Consumption } \\
\text { Permanent economy }\end{array}$ \\
\hline 7 & $\begin{array}{l}\text { Imported natural } \\
\text { capital } \\
\text { Technical } \\
\text { infrastructure }\end{array}$ & $\begin{array}{l}\text { Material and energy } \\
\text { flows } \\
\text { Transport network }\end{array}$ & $\begin{array}{l}\text { Resources } \\
\text { Origin } \\
\text { Water } \\
\text { management }\end{array}$ & $\begin{array}{l}\text { Energy network } \\
\text { Waste } \\
\text { management }\end{array}$ & $\begin{array}{l}\text { Consumption } \\
\text { costs/revenues } \\
\text { Communication } \\
\text { Information and } \\
\text { communication } \\
\text { technologies }\end{array}$ \\
\hline 8 & $\begin{array}{l}\text { Communities } \\
\text { Municipalities }\end{array}$ & $\begin{array}{l}\text { Housing } \\
\text { House owners }\end{array}$ & $\begin{array}{l}\text { Natural } \\
\text { demographic } \\
\text { change }\end{array}$ & $\begin{array}{l}\text { Migration } \\
\text { Mobility }\end{array}$ & $\begin{array}{ll}\text { Cooperation and } \\
\text { conflicts } \\
\text { Institutions }\end{array}$ \\
\hline 9 & Social services & Education & Health & Administration & $\begin{array}{ll}\begin{array}{l}\text { Financial, } \\
\text { remedial, etc. }\end{array} & \\
\end{array}$ \\
\hline 10 & Visitors & $\begin{array}{l}\text { (Eco)tourism } \\
(\text { Eco)sports }\end{array}$ & Second homes & Chalets/cottages & Other activities \\
\hline 11 & Culture & Lifestyle & $\begin{array}{l}\text { Public space } \\
\text { Sacral spots }\end{array}$ & $\begin{array}{l}\text { Cultural production } \\
\text { Organisations }\end{array}$ & $\begin{array}{l}\text { Municipal plan } \\
\text { Improvement }\end{array}$ \\
\hline
\end{tabular}




\begin{tabular}{|l|l|l|l|l|l|}
\hline & & & & & Management \\
\hline 12 & Sustainability & Social learning & Public hearings, & Programmes & Households/ \\
& Security/safety & Legislation & debates and & Projects & municipalities as \\
& Coherence & Agenda 21 & discussions & Actions & ecosystems \\
& Values & Local action groups/ & Government & Scenarios & Regulation \\
& Changes & LEADER & & Renaturalisation & Managerial forces \\
& Responses & & & Restoration & \\
\hline
\end{tabular}

To explain how the educational component is connected with the practical one in the functional model of the Deblínsko project, we will use Epstein (2009), who works with two theoretical models. In the external model (see Fig. 2), he emphasises groups that act upon the child/pupil: the family, school and community. In our case, the primary school is supported by the university, which is also involved in communication with the Deblín community: we have carried out several meetings with citizens, who included a number of parents, so that Epstein's model can be implemented in practice. Moreover, the university's academicians have been invited by the primary school teachers directly to teach along with the university students. This involved primarily field sustainability teaching, which requires deeper knowledge. The university students led teaching in information and communication technologies at the primary school as well, such as deployment of geographical information systems in studying local sustainability. Awareness and working with the finding that each group brings into the mutual interactions experience, philosophical framework and activities that create them is the precondition for cooperation. Experts coming from outside the area are well capable of accentuating this model in particular. In our case, this is the Masaryk University institute above all.

\section{External Structure}

Force B

Experience, Philosophy, Practices of Family

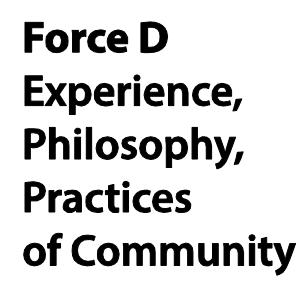

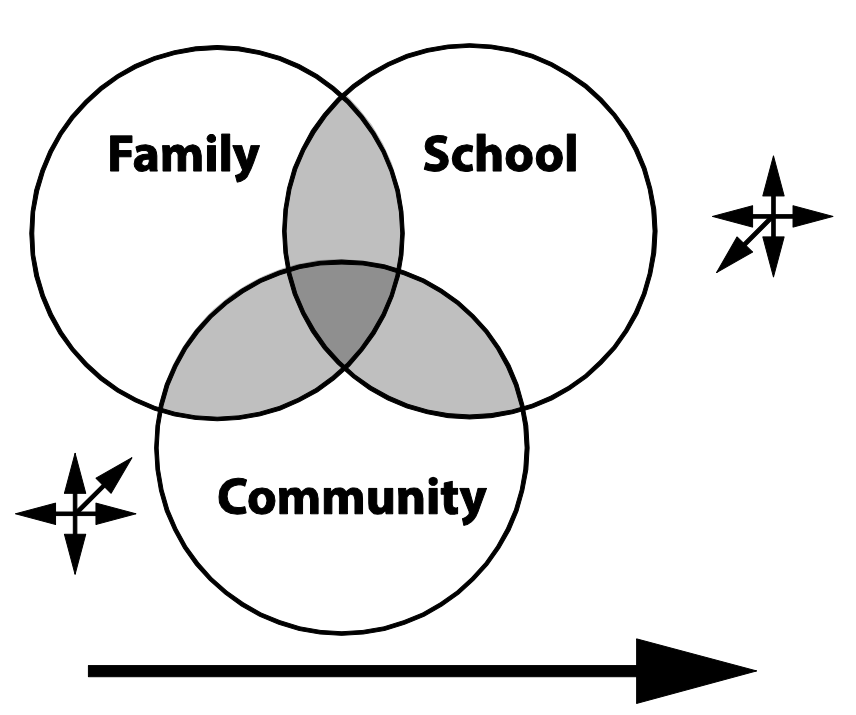

Force A
Force C Experience, Philosophy, Practices of School

\section{Time/Age/Grade Level}

Fig. 2: External model according to Epstein (2009) 
The internal model (see Fig. 3) works primarily with interactions between the family and school. Here, B. Svozil's role and its transformation (teacher - headmaster) was important, along with a certain associated degree of power or influence on involvement, as well as establishment of community processes.

\section{Internal Structure}

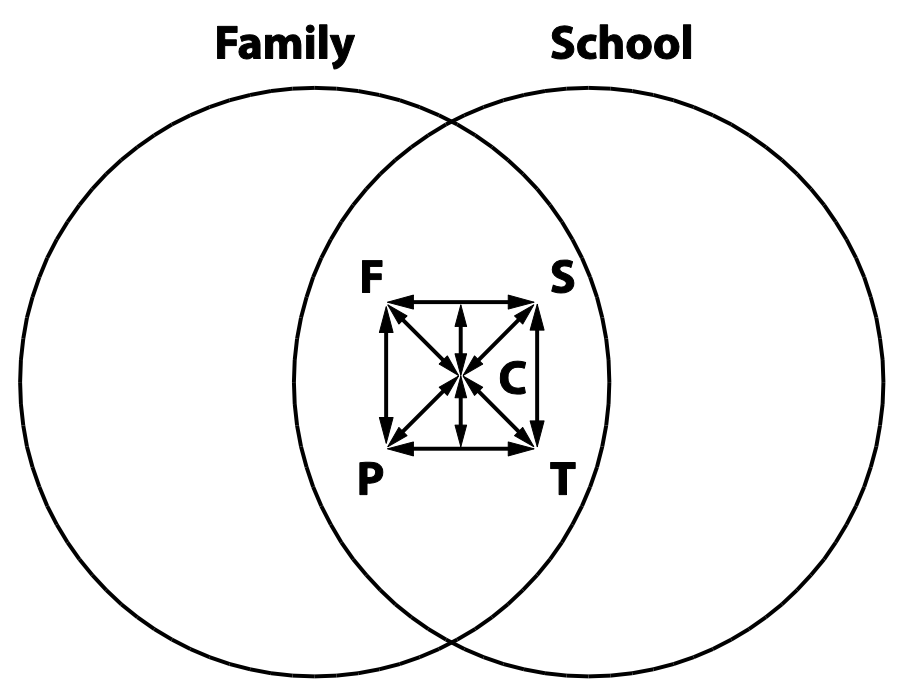

Fig. 3: Internal model according to Epstein (2009).

Key inter-institutional interactions (in overlapping areas):

$\mathrm{F}=$ Family; $\mathrm{C}=$ Child; $\mathrm{S}=$ School; $\mathrm{P}=$ Parent; $\mathrm{T}=$ Teacher.

Interactions include those at the institutional level and at the individual level.

The outcome of application of this model is, as stated by Davis (2010) in ÄrlemalmHagser (2013), that the children are now recognised as able, strong-willed and active individuals, citizens with the right to be involved and be heard in matters that concern them.

\section{Results and discussion}

The revision of the theoretical and methodological approaches reflects the activities of a stakeholder team, based on the following assumptions:

- transformation of roles from observer to participation in community processes;

- $\quad$ site survey and understanding - must be based on detailed knowledge of the site/community and correct interpretation of community processes;

- $\quad$ children/pupils are the means of starting community transformations;

- $\quad$ the research is long-term.

These activities have succeeded in stimulating the development of pupils towards the role of conscious and responsible citizens who understand the needs of their surroundings and show an effort to be involved in their future development. The pupils' activity has helped provoke the local inhabitants' interest in the surroundings of their 
homes, develop their sensitivity towards sustainability principles, and motivated them for active involvement in the project. For pupils and students alike, the project is an exceptional opportunity to participate in outcomes that are progressively presented and discussed with representatives of public administration and local self-governance with the aim to reflect or implement them in practice.

The research component has evolved along with the local activities. A. Hynek and B. Svozil empowered the social research in both the subjects by deployment of qualitative and ethnographic methods, which have now both been adapted into the participatory action research. The book by Cloke et al. (2004) turned out to be methodologically important, as it deals with not only structure of geographic data in its first part, but a brand new method of interpretation of geographic data in the second part. It is this second part that brings an emphasis on geographic thinking meeting the requirement for developing Bloom's taxonomy of educational objectives mentioned above as done by Anderson and Krathwohl (2001) as well as Marzano and Kendall (2006) at the metacognitive level.

A new education and research team, led by A. Hynek, was set up in 2008 with students of doctoral programmes of B. Svozil, J. Trávníček and J. Trojan. The decisive impulse came with B. Svozil's becoming a teacher at the Deblín Primary School, and its headmaster later on. Based on the revised theoretical and methodological concepts mentioned above, A. Hynek and B. Svozil reworked the educational objectives of the subjects Z0131 Sustainability and Z0132 Urban and Rural Studies, taught at the Masaryk University Department of Geography, while J. Trávníček and J. Trojan integrated advanced geoinformation methods into the two subjects. Results of work of students, who have appreciated the connection of the field studies with the GIS technology application, have been regularly published since then. The university students have thus entered an area in which B. Svozil has oriented geography education towards sustainability, and had no difficulty communicating with the primary school pupils, who knew the Deblín area differently from them. This resulted in an interdigitation of the university students' expertise and external "unbiased" view with the internal knowledge and sensitive perception of Deblín Primary School pupils as local experts. An important project component was the development of two local textbooks (Svozil and Hynek, 2011, 2012) and the Deblínsko Atlas (Trávníček and Trojan, 2011), a series of articles published domestically and abroad, and most importantly, implementation of project teaching/learning at both the Primary School and the MU Department of Geography, which complies with the educational objectives of Bloom, Anderson/Krathwohl and Marzano/Kendall. This is a turn towards critical and creative thinking, sensorimotor activity and effective formative education. Dlouhá (2002) brought important inspiration by formulating this type of pedagogy, with which we have affiliated and added our own sustainability curriculum.

\section{Conclusion}

The cooperation of a university with a rural primary school is not usual: academicians perceive themselves as too high up, and rural schools as too low down. Yet, the sustainability theme is a potential keystone of their cooperation: academicians are not as masterful in the rural terrain as they are in the city, and country people often know their environment with remarkable precision. The municipality has launched a type of governance (see above) that has meant a rise in the social life and practical politics. The cooperation has given rise to a new concept of the Deblín school, which now uses the 
motto "Sustainable learning school". We understand this learning school so that the educational process is not along the lines of one-way teacher-pupil communication, but also pupil-teacher, pupil-teacher-parent, teacher-community, etc. The increasing number of combinations ultimately means that everyone is a pupil. The learning school can also be interpreted as constantly evolving teachers = constantly evolving school (spiral model). If the practice succeeds in fulfilling this, the school also becomes a place of innovation. In this context, the accent on personal sustainability is important: how much and what we say is not as important as what we do and how. If we want to pass these principles down, teaching them is not enough: we should live according to them, which is the point of the personal approach.

The primary school has begun to change its established ways (routine activities) towards an open school, and community (social and cultural) centre in a sense. The school has become a part of functioning networks - either it creates networks or participates in them. In a sense, it can be referred to as a globalisation product, combining global influences on the municipality and their adaption based on local natural and social capacities. The school thus no longer plays only the conventional educational role, but also the role of a cementing element; it unites the community, or at least tries to invite it to do so. This change makes room for new actors and their actions, which lead to new discourses that enhance, even with non-discursive practices, the promotion of sustainability in the place's community life. Ultimately, therefore, the changes are contributing to increasing the school's prestige, community status, but on the other hand, this is associated with greater interlinkage with the municipal administration. With an appropriate clear setting and respecting of positions, this can be beneficial for sustainability. Naturally, this approach raises the requirements on all those involved.

\section{Acknowledgement}

Development of the former version of the case study has been supported from the project OP VK CZ.1.07/2.4.00/17.0130 "Interdisciplinary Network for Policy Development in Sustainable Development Field" funded through the Education for Competitiveness Operational Programme via the Czech Ministry of Education, Youth and Sport http://mosur.czp.cuni.cz.

\section{References}

- Adams, W. (2006). The Future of Sustainability: Re-thinking Environment and Development in the Twenty-first Century. Report of the IUCN Renowned Thinkers Meeting. United Kingdom: IUCN. Available from: http://cmsdata.iucn.org/downloads/iucn_future_of_sustainability .

- Alcamo J. et al. (2003). Millennium Ecosystem Assessment - Ecosystems and Human Well-being - A Frame for Assessment. Ecosystems and Human Well-being. A Report of the Conceptual Framework Working Group of the Millennium Ecosystem Assessment. Washington, D.C.: Island Press.

- Alcamo, J. et al. (2003a). Ekosystémy a kvalita lidského života: Rámec pro hodnocení. Zpráva pracovní skupiny pro koncepční rámec Ekosystémového hodnocení milénia. Praha: Ministerstvo životního prostředí 
- Anderson L. and Krathwohl D. A. (2001). Taxonomy for Learning, Teaching and Assessing: A Revision of Bloom's Taxonomy of Educational Objectives. New York, NY: Longman.

- Ärlemalm-Hagser E. (2013). Respect for nature - a prescription for developing environmental awareness in preschool. CEPS Journal 3 (1), 25-44.

- Le Blanc, D., Roehri, R. A. (2012). Back to Our Common Future Sustainable Development in the 21st century (SD21) project Summary for policymakers. Available from: http://sustainabledevelopment.un.org/content/documents/UNDESA_Back_Common_Future_En.pdf.

- Berg, B. (2004). Qualitative research methods for the social science (5th ed.). Boston, MA: Pearson Education.

- Bloom, B. ed. (1956). Taxonomy of educational objectives: the classification of educational goals; Handbook I: Cognitive Domain. New York, NY: Longmans, Green.

- Chevalier J.M., Buckles D.J. (2013). Participatory Action Research: Theory and Methods for Engaged Inquiry. London: Routledge UK.

- Cloke P., Cook I., Crang P., Goodwin M., Painter J., Philo C. (2004). Practising Human Geography. London: Sage Publications.

- Davis J. (2008). What might education for sustainability look like in early childhood?. The contribution of early childhood education to a sustainable society. Paris: UNESCO Publications.

- Declaration of the United Nations Conference on the Human Environment. (1972). Report of the United Nations Conference on the Human Environment. Stockholm. Available from:

http://www.unep.org/Documents. Multilingual/Default.Print.asp?documentID $=97$ and ArticleID $=1503$.

- Deleuze G. (2003). Foucault. Praha: Herrmann and synové.

- Dlouhá J., ed. (2002). Inovace vysokoškolské výuky v environmentálních oborech. Praha: Univerzita Karlova, Centrum pro otázky životního prostředí.

- Duncan A. (2012). New Taxonomy of Education Objectives - Marzano and Kendall, 2007, slide 3. Available from:

- http://www.slideshare.net/Amberagd/new-taxonomy-of-educational-objectives

- Foucault, M. (1999). Dějiny sexuality 1, Vưle k vědění. Praha: Herrmann and synové

- Foucault, M. (2000). Dohližet a trestat. Praha: Dauphin.

- From Outcome to Implementation. (2013). Our Planet. Nairobi: UNEP. Available from: http://www.unep.org/pdf/OP-FEB-EN-2013.pdf. 
- Fugueiredo L., Amorim L. (2007). Decoding the urban grid: or why cities are neither trees nor perfect grids. Proceedings, $6^{\text {th }}$ International Space Syntax Symposium. Istanbul, 2006.

- Griggs D., et al (2013). Sustainable development goals for people and planet. Nature, vol. 405, pp. 305-307. Available from: http://sustainabledevelopment.un.org/content/documents/844naturesjournal.pdf.

- Heffron S., Downs R. (2012). Geography for Life: National Geography Standards, 2nd ed. Geography Education National Implementation Project. Washington, D.C.: National Council for Geographical Education.

- Hynek, A. et al. (1985): The Fryšávka drainage basin strategy as proposed by geographical workshop group of Brno university. Scripta Fac. Sci. Nat. Univ. Purk. Brun., Geographia 15, 139-157.

- Hynek, A., Svozil, B., Trávníček, J., and Trojan, J. (2009). Trvalá udržitelnost Deblínska: Vzdělávací projekt. Envigogika, 4(2). Available from http://envigogika.cuni.cz/index.php/Envigogika/article/view/40 DOI: http://dx.doi.org/10.14712/18023061.40

- Hynek A., Svozil B., Vágai T., Trávníček J., Trojan J. (2010): Sustainability in Practice. In: A.Barton, J.Douhá, eds.: Multi-Actor Learning for Sustainable Regional Development in Europe: A Handbook of Best Practice. Grosvenor House Publishing Limited, Guildford. 343 pp., pp. 215-233.

- Hynek, A., Svozil, B., Trávníček, J., and Trojan, J. (2011). Best Practice Example of Educational Project: Sustainability in Deblín, South Moravia, Czech Republic. In: A. Demirci, L. Chalmers, Y. Ari, J. Lidstone, eds.: Building Bridges between Cultures through Geographical Education - Proceedings of the IGU-CGE Istanbul Symposium: July 8-10, 2010, IGU Commission on Geographical Education, Fatih University. 307 pp., pp. 23-30.

- Hynek, A., Svozil, B., Vagai, T., Trávníček, J., and Trojan, J. (2011). D. Sustainability in Practice. Multi-Actor Learning, 215.

- Hynek A., Vávra J. (2012). Dešifrovací klíč k současným geografiím. Available from: http://www.kge.tul.cz/attachments/article/327/Desifrak.pdf.

- Hynek A. (2013). Deblínsko ve výuce trvalé udržitelnosti. In: Diviaková, A. (ed.), 2013: Vybrané aspekty integrovaného manažmentu životného prostredia. Zborník vedeckých príspevkov z konferencie konanej 12. septembra 2013 vo Zvolene, Katedra UNESCO pre ekologické vedomie a TUR, FEE TU vo Zvolene, 234 pp., pp. 179-191

- Kates, R., Thomas M. Parris, and Anthony A. Leiserowitz. (2005). What is sustainable development? Environment 47(3). 9-21.

- Kohoutek R. (2015). Akční výzkum. Available from: http://slovnik-cizich slov.abz.cz/web.php/slovo/akcni-vyzkum

- Marzano, R.J. and J.S. Kendall, eds. (2007). The New Taxonomy of Educational Objectives. 2nd ed. Thousand Oaks, California: Corwin Press. Available from: http://thekglawyerblog.com/ptblog/articles/from-bloom-to-marzano-a-newtaxonomy-of-educational-objectives-for-plt/. 
- Millennium Development Goals. (2000). Available from: http://www.alliance2015.org/fileadmin/user_upload/MDGs.pdf.

- Millennium Ecosystem Assessment (2005). Ecosystems and Human Well-being: Synthesis. Washington, D.C.: Island Press.

- The National Environmental Policy Act of 1969. Pub. L. 91-190, 42 U.S.C. 43214347, January 1, 1970, as amended by Pub. L. 94-52, July 3, 1975, Pub. L. 94-83, August 9, 1975, and Pub. L. 97-258, § 4(b), Sept. 13, 1982. Available from: http://ceq.hss.doe.gov/nepa/regs/nepa/nepaeqia.htm.

- Nilsson P. (2012). Sense and Sensation. Writing on Creativity, Education, Philosophy, and Cognitive Science. Available from:

http://www.senseandsensation.com/2012/03/taxonomies-of-six-educational.html.

- Pol, M., Hloušková, L., Lazarová, B., Novotný, P., Sedláček, M. (2013). Když se školy učí. Brno: Masarykova univerzita.

- Report of the World Commission on Environment and Development: Our Common Future. (1987). New York, NY: United Nations World Commission on Environment and Development. A/42/427.

- Le Blanc, D., Liu, W., O'Connor, D., Zubcevic I. (2012). Rio+20 working papers Issue 1: Development cooperation in the light of sustainable development and the SDGs: Preliminary exploration of the issues Division for Sustainable Development, UNDESA. UN Division for Sustainable Development. Available from:

http://sustainabledevelopment.un.org/content/documents/761 workingpaper3.pdf.

- Svozil, B., Hynek, A. (2011). Deblínsko: na cestě k trvalé udržitelnosti. Deblín. (ESF, MŠMT): ZŠ a MŠ Deblín.

- Svozil, B., Hynek, A. (2012). Dvojjazyčná učebnice terénního učení - Deblín a okolí. Czech-English Textbook of Outdoor Learning: Deblín and its Surroundings. Deblín. (ESF, MŠMT): ZŠ a MŠ Deblín.

- Trojan, J., Trávníček, J. (2011): Atlas Deblínska. Brno: Geodis.

- United Nations Conference on Environment and Development Rio de Janerio, Brazil, 3 to 14 June 1992. AGENDA 21. Available from:

http://sustainabledevelopment.un.org/content/documents/Agenda21.pdf.

- Vávra, J. (2011). Proč a $k$ čemu taxonomie vzdělávacích cillu. Available from: clanky.rvp.cz/clanek/o/z/11113/PROC-A-K-CEMU-TAXONOMIE-VZDELAVACICHCILU.html.

- World Conservation Strategy, Living Resource Conservation for Sustainable Development. (1980). IUCN-UNEP-WWF, Gland.

- Wright, T. (2002). Definitions and frameworks for environmental sustainability in higher education. Higher Education Policy 15. 105-120. Amsterdam: Elsevier, Int. Assoc. of Universities. 
Břetislav Svozil - Headmaster's Office of Deblín Primary School and Kindergarten

Jakub Trojan - Institute of Geonics of the Academy of Sciences of the Czech Republic, v.v.i.

Jan Trávníček - The Nottingham Trent University, U.K. 